\title{
Viral Genome-Linked Protein (VPg) Controls Accumulation and Phloem-Loading of a Potyvirus in Inoculated Potato Leaves
}

\author{
Minna-Liisa Rajamäki and Jari P. T. Valkonen \\ Department of Plant Biology, Genetics Centre, SLU, P.O. Box 7080, S-750 07 Uppsala, Sweden; and Institute \\ of Biotechnology, University of Helsinki, Finland
}

Submitted 30 July 2001. Accepted 8 October 2001.

\begin{abstract}
The viral protein covalently linked to the $5^{\prime}$ end of the plussense, single-stranded RNA genome of potyviruses (genus Potyvirus) can be an avirulence determinant in incompatible potyvirus-host combinations in which the resistance prevents systemic virus infection. The mechanism is not well known. This study shows that virus strain-specific resistance to systemic infection with Potato virus $A$ (PVA) in Solanum commersonii is overcome by a single amino acid (aa) substitution, His118Tyr, in the viral genome-linked protein (VPg). Virus localization and other experiments revealed that Tyr $^{118}$ controls phloem loading of PVA. The critical boundary may be constituted in phloem parenchyma, companion cells, or both. Tyr ${ }^{118}$ also controls the cellular level of virus accumulation in infected leaves, including phloem cells. Amino acid substitutions at three additional positions of the central part (aa 116) and $C$ terminus (aa 185) of the VPg and of the N terminus of the $6 \mathrm{~K} 2$ protein (aa 5) affect virus accumulation and rate of systemic infection but are not sufficient for phloem loading of PVA. These data, together with previous studies, indicate that the PVA VPg aa residues crucial for systemic infection are host specific. Also, our data and previous studies on other potyvirus-host species combinations indicate that the central part of the VPg is a domain with universal importance to virus-host interactions required for systemic invasion of plants with potyviruses.
\end{abstract}

Systemic infection of plants with viruses involves virus replication in the initially infected epidermal or mesophyll cells; cell-to-cell movement through plasmodesmata into and through vascular tissue; loading into and long-distance transport through sieve elements (SE) following partitioning of photoassimilates; and unloading from SE followed by cell-to-cell movement and infection of other parts (Carrington et al. 1996; Ruiz-Medrano et al. 2001; Santa Cruz 1999). The virus-encoded movement proteins (MPs) are needed for intracellular transfer of the virus to plasmodesmata and for plasmodesmal regulation to allow passage of virus to the next cell (Crawford and Zambryski 2001; Ding 1998; Oparka and Turgeon 1999). Members of the genus Potyvirus do not encode dedicated MPs but have several multifunctional proteins involved in both viral movement and other functions (Urcuqui-Inchima et al. 2001). The singlestranded, messenger-polarity RNA genome of potyviruses is translated into a large polyprotein that is subsequently processed to 10 functional proteins by three virus-encoded pro-

Corresponding author: Jari Valkonen; E-mail: jari.valkonen@vbiol.slu.se teinases. Of these proteins, the cylindrical inclusion protein (CI; RNA helicase) (Carrington et al. 1998) and the coat protein $(\mathrm{CP})$ are required for cell-to-cell movement (Dolja et al. 1994, 1995; Varrelmann and Maiss 2000). Since the virion assembly motifs within the core of the $\mathrm{CP}$ are required for virus movement, potyviruses may be transported as virions or other viral RNA-protein complexes including partially assembled CP (Carrington et al. 1996). The CP is also needed for vascular transport, but this function involves the surface-exposed $\mathrm{N}$ and C-terminal domains of the CP (Dolja et al. 1994, 1995). The helper-component proteinase (HC-Pro) is a trans-acting, vascular movement-associated protein (Cronin et al. 1995; Kasschau et al. 1997) that also suppresses the host antiviral defense mechanism called RNA silencing (Marathe et al. 2000).

The viral genome-linked protein $(\mathrm{VPg})$ is a multifunctional protein involved in viral genome amplification and movement. It is the N-proximal part of the nuclear inclusion protein a (NIa) protein and autocatalytically separated from the C-proximal proteinase domain (NIa-Pro) of the NIa at a suboptimal cleavage site (Murphy et al. 1990; Shahabuddin et al. 1988). Due to a nuclear localization signal (amino acids [aa] 40 to 49 in the VPg of Tobacco etch virus [TEV]), the VPg (or NIa) predominantly accumulates in the nuclei (Carrington et al. 1991; Schaad et al. 1996). NIa interacts with several other proteins of the putative viral replication complex (Fellers et al. 1998; Guo et al. 2001; Merits et al. 1999). The VPg is covalently bound to the $5^{\prime}$ end of the viral RNA by a phosphodiester bond via a conserved tyrosine residue located at the $\mathrm{N}$-proximal part (aa 60 in Tobacco vein mottling virus [TVMV]), which is required for infectivity (Murphy et al. 1991, 1996). The VPg-RNA linkage is not disrupted at virion assembly, and the VPg remains a part of the virions (Murphy et al. 1990; Oruetxebarria et al. 2001). The VPg also interacts with the translation initiation factor eIF(iso)4E (Schaad et al. 2000; Wittmann et al. 1997), which in Turnip mosaic virus is mediated by Asp at position 77 and required for systemic infection (Leonard et al. 2000). Furthermore, aa substitutions at positions 105 to 117 of the VPg render Pea seedborne mosaic virus (PSbMV) noninfectious in pea plants with the recessive resistance gene $s b m-1$ (Borgstrøm and Johansen 2001; Keller et al. 1998). Thus, many lines of evidence implicate involvement of the VPg in potyvirus multiplication (replication, translation, or both).

Involvement of the VPg in movement of potyviruses has been discovered recently. In this respect, plants restrictive to potyvirus movement due to natural resistance mechanisms have been instrumental. Tobacco plants homozygous for the recessive resistance gene $v a$ are not systemically infected with TVMV due to defective viral cell-to-cell movement in the 
mesophyll of inoculated leaves; four aa substitutions in the VPg overcome the resistance (Nicolas et al. 1997). The isolate HAT of TEV moves cell to cell in inoculated leaves of tobacco cv. V20, infecting also parenchyma and companion cells in the vascular tissue, but no systemic infection is observed; it was not reported whether virus loading to, or exit from, SE was blocked. Amino acid substitutions within a short region of the VPg overcome the resistance (Schaad and Carrington 1996; Schaad et al. 1997). A single aa substitution in the VPg of Potato virus A (PVA, isolate $\mathrm{M}$ ) overcomes resistance to systemic infection in Nicandra physaloides (L.) Gaertner, but other aa substitutions in the VPg and the 6K2 protein are also important (Rajamäki and Valkonen 1999). The VPg of PVA is also a virus isolate-specific determinant of systemic infection in an interspecific potato hybrid, and in this case, the HC-Pro, the CP, or both are needed as auxiliary factors for overcoming resistance
(Hämäläinen et al. 2000). The cellular boundaries at which the movement of PVA is blocked have not been determined. The movement functions of the VPg appear to be independent from its functions in virus multiplication (Nicolas et al. 1997; Schaad et al. 1997).

PVA is an important pathogen of potato (Solanum tuberosum L.) in many potato-growing areas, reducing yields by up to $40 \%$ (Bartels 1971). PVA infects other species of the family Solanaceae, including tamarillo (S. betaceum Cav.), in the field (Eagles et al. 1990), and many other species of the family Solanaceae can be experimentally infected (Bartels 1971). In this study, we investigated virus strain-specific resistance to PVA in $S$. commersonii Dunal ex Poiret, a wild potato species widely used as a source of genes for freezing tolerance and cold acclimation in potato-breeding programs (Chen et al. 1999; Seppänen 2000). Accession PI 458319 of S. commersonii is

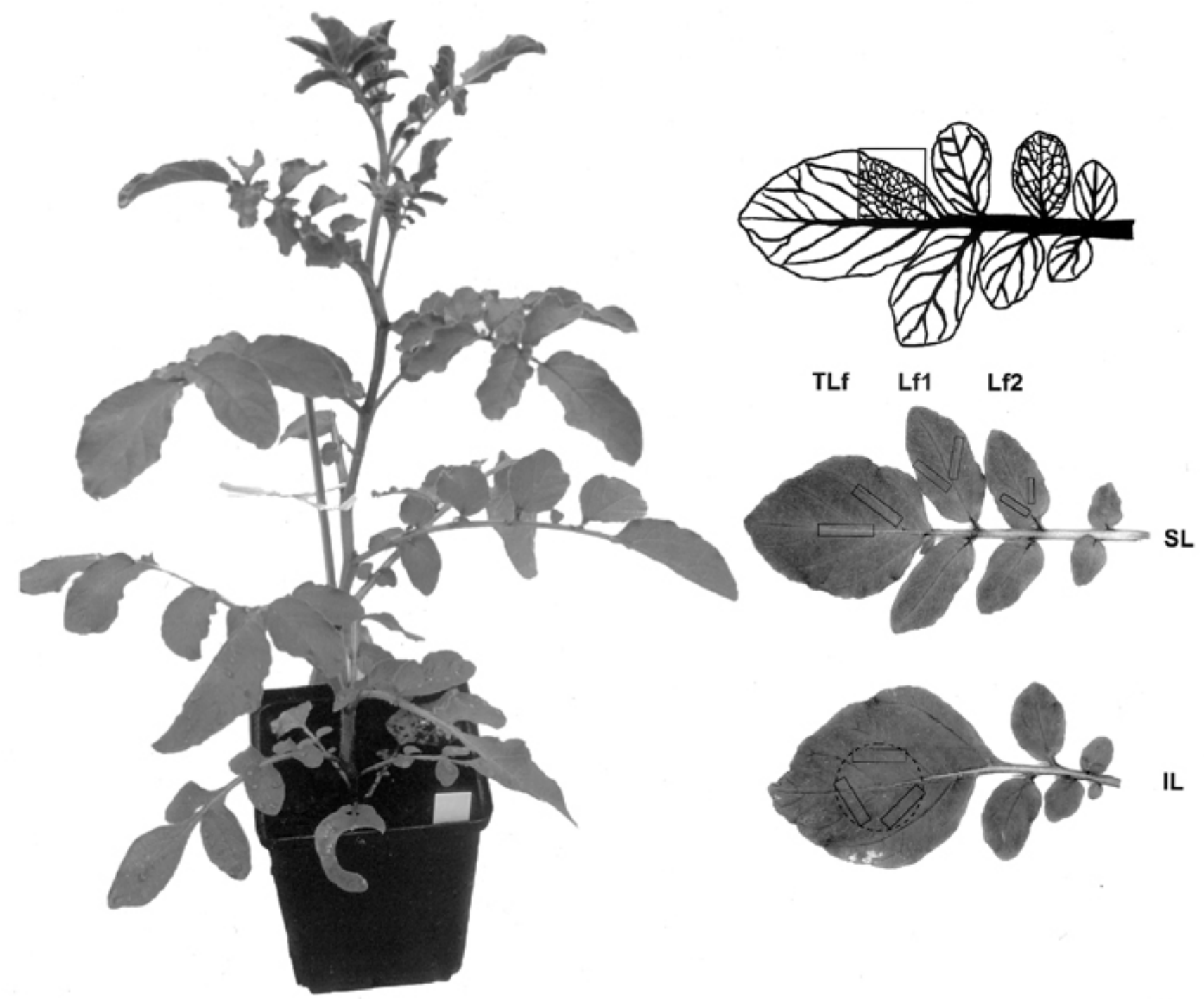

Fig. 1. Transition from simple to final composite leaf morphology, venature of leaves, and sampling of leaf tissue for virus localization in Solanum commersonii. IL (inoculated leaf), a lower leaf with simple morphology. The terminal leaflets of the three lowest leaves were inoculated. The leaf area inoculated with viral cDNA using particle bombardment and later studied for virus accumulation is circled (see the plant to the left for an inoculated leaf from which a sample has been taken). SL (systemically infected leaf), an upper, fully expanded leaf (position 8) with a composite morphology situated five positions above the inoculated leaves; a side leaflet from this and the next three upper leaves were sampled and combined for determination of systemic infection by enzyme-linked immunosorbent assay unless stated otherwise in text. Boxes in IL and SL indicate the positions from which tissue was excised for fixation, embedding, and virus localization with immunostaining, in situ hybridization, or both. TLf, terminal leaflet; Lf1, first lateral leaflet; and Lf2, second lateral leaflet. Diagrammatic representation of vein classes in a leaf of S. commersonii is shown on the top. Vein classes I and II are illustrated on all leaflets. Veins of classes I to III are shown on one lateral leaflet, whereas veins of classes I to IV are indicated for a marked area in the terminal leaflet. Note that the plant to the left was photographed 35 days postinoculation (dpi) to illustrate the morphology of $S$. commersonii PI 458319 , whereas samples for virus analyses were taken at 11 to $17 \mathrm{dpi}$. Final composite leaf morphology in S. commersonii includes four lateral leaflets (upper leaves on the plant to the left). 
susceptible to all common potato viruses, including PVA (Valkonen 1997), except the so-called tobacco strain of PVA (isolates obtained from potato but propagated in Nicotiana spp. over 20 years; Rajamäki et al. 1998), which causes no systemic infection (J. Valkonen, unpublished data). We use "avirulent" to denote an inability of the virus to cause a normal systemic infection in the host, and we use "avirulence determinant" instead of "avirulence factor" to reflect the fact that the genetic basis of resistance to PVA is unknown in $S$. commersonii. The aim of this study was to identify the avirulence determinants in isolate B11 and to study the cellular boundaries at which systemic infection of B11 was inhibited in S. commersonii. The results show that a single aa residue at the central part of the VPg controls loading of PVA into the phloem and also affects the cellular level of virus accumulation in infected leaves. Virus localization studies indicated that resistance to vascular transport was probably manifested in the vascular parenchyma, in companion cells, or in both. Three additional aa substitutions at the central part and $\mathrm{C}$ terminus of the VPg and at the $\mathrm{N}$ terminus of the $6 \mathrm{~K} 2$ protein affected virus accumulation and rate of systemic infection, but they were not sufficient for restoration of phloem loading of B11.

\section{RESULTS}

\section{Venature of leaves of $S$. commersonii.}

The composite leaves of the cultivated potato ( $S$. tuberosum) consist of a terminal leaflet and three or four lateral leaflets. However, the first leaves may be simple or contain only a few lateral leaflets. A transition from simple to the final composite leaf morphology occurs while new leaves develop (Hayward 1938; McCauley and Evert 1988a). Similar transition in morphology is observed in S. commersonii (Fig. 1).

The leaflets of cultivated potato have six or seven vein orders or classes, implying that each successive vein branches to derive the next order. The class II veins diverge from the midvein (class I) at an acute angle. They do not (always) terminate at the margin but turn upward and are connected to the next class II vein (McCauley and Evert 1988a). Class III and some class IV veins are considered major veins because they contain rib tissue. The minor veins (classes V to VII) are those embedded in mesophyll tissue (McCauley and Evert 1988a).

The venature of leaves of $S$. commersonii that were examined for localization of PVA proteins and RNA in this study is similar to the cultivated potato (Fig. 1). Class I to class III veins are major veins containing rib tissue throughout their length, whereas the higher class veins are partially (class IV) or entirely (classes V to VII) embedded in mesophyll and are considered minor veins. Categorizing the minor veins to the

Table 1. Infection of Solanum commersonii with Potato virus A isolates

\begin{tabular}{lcc}
\hline & \multicolumn{2}{c}{ Relative amounts of virus $^{\mathbf{a}}$} \\
\cline { 2 - 3 } Isolate & Inoculated leaves & Upper noninoculated leaves \\
\hline Ali & 59 & 0 \\
B11 & $100^{\mathrm{b}}$ & 0 \\
M & 8 & 58 \\
U & 27 & 77 \\
TamMV & 32 & $100^{\mathrm{c}}$ \\
\hline
\end{tabular}

${ }^{a}$ Virus amounts relative to the isolate that accumulated to the highest amounts in sap-inoculated leaves at 12 to 15 days postinoculation (dpi) and in the upper noninoculated leaves at 15 to 18 dpi. Virus amounts were estimated by enzyme-linked immunosorbent assay using known amounts of purified virions for comparison. Results are combined from four independent experiments, each including two to three plants per virus isolate.

${ }^{\mathrm{b}}$ Mean amount of B11 used as the reference $(3,340 \mathrm{ng} / \mathrm{g}=100)$.

${ }^{\mathrm{c}}$ Mean amount of TamMV used as the reference $(335 \mathrm{ng} / \mathrm{g}=100)$. different vein classes was not systematically done, since previous authors (McCauley and Evert 1988a, 1988b, 1989) have noted that at the end of a vein the anatomy changes and resembles the anatomy of the next higher class of veins. Furthermore, the minor veins can be connected to any other major or minor class of veins (McCauley and Evert 1988a). Therefore, we often refer to major veins or minor veins, without specifying the order (class).

The vasculature and vein anatomy of potato have been described in detail (Hayward 1938; McCauley and Evert 1988a, 1988b, 1989). Potato has bicollateral vascular bundles containing both abaxial phloem (ABph) and adaxial phloem (ADph), referring to the phloem situated toward the lower and upper side of a leaf lamina in a vascular bundle, respectively. However, the highest vein order never contains ADph (McCauley and Evert 1989). A majority of the phloem tissue in leaves consists of $\mathrm{ABph}$, and $\mathrm{ABph}$ and $\mathrm{ADph}$ have anatomical differences. For example, ADph contains dead SE not usually observed in ABph. In ADph, the ratio of companion cells (CC) and $\mathrm{SE}$ does not exceed $1: 1$, in contrast to $\mathrm{ABph}$. On the other hand, in $\mathrm{ABph}$, the frequency of plasmodesmata markedly drops between the phloem parenchyma cells and CC-SE complex, which is not observed in ADph (McCauley and Evert 1989). However, since plasmodesmata also occur in aggregates, previous authors have questioned the significance of counts of plasmodesmal frequencies as an indicator of the predominant phloem transport pathway in different veins (McCauley and Evert 1989). Very few, if any, plasmodesmata have been observed between parenchyma cells (VPC) and SE in the phloem of potato (McCauley and Evert 1989), which suggests that phloem loading of macromolecules, including viruses, from VPC to SE may occur via CC (Ding et al. 1998).

Cell identification in phloem is possible in species of the family Solanaceae using microscopy and positional analysis. The nomenclature of phloem cells has been comprehensively described and illustrated in potato (McCauley and Evert 1988a, 1988b, 1989) and other solanaceous species (Ding et al. 1998) and was adopted for use in this study.

\section{Systemic infection with PVA isolates in S. commersonii.}

Plants of $S$. commersonii were systemically infected with PVA isolates $\mathrm{M}, \mathrm{Sab}$, and $\mathrm{U}$ (potato strains) and TamMV

\begin{tabular}{|c|c|c|c|c|c|}
\hline \multirow[t]{2}{*}{$\sum \mathrm{Cl}$} & \multirow{2}{*}{$6 \mathrm{~K} 2$} & \multicolumn{2}{|c|}{ VPg } & \multicolumn{2}{|c|}{$\begin{array}{l}\text { Nla- } \\
\text { Pro }\end{array}$} \\
\hline & & & & 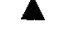 & \\
\hline & 5 & 116 & 118 & 185 & inf. \\
\hline B11 & v & M & H & 5 & - \\
\hline B11-v1 & M & M & H & s & \\
\hline B11-v4 & $\mathbf{v}$ & M & $\mathbf{Y}$ & $\mathbf{s}$ & + \\
\hline B11-v5 & v & M & H & $\mathbf{L}$ & - \\
\hline $\mathrm{B} 11-\mathrm{v} 2,4$ & v & v & $\mathbf{Y}$ & $s$ & + \\
\hline B11-M & M & $\mathbf{v}$ & $\mathbf{Y}$ & L & + \\
\hline B11-M2 & M & M & $\mathbf{Y}$ & L & + \\
\hline B11-M5 & M & v & $\mathbf{Y}$ & $\mathbf{s}$ & + \\
\hline B11-M1,2 & v & M & $\mathbf{Y}$ & L & + \\
\hline
\end{tabular}

Fig. 2. Schematic map of the genomic region between the unique restriction sites SwaI(5163) and ApaI(6370) in the infectious cDNA of isolate B11 and to which amino acid substitutions were introduced. The depicted region was replaced with the corresponding region cloned from isolate $\mathrm{M}$, and the recombinant virus was designated as B11-M. Other mutants were generated by site-directed mutagenesis of B11 cDNA (designated as B11-v...) or B11-M (B11-M...). The four amino acids in the $6 \mathrm{~K} 2$ protein and the viral genome-linked protein $(\mathrm{VPg})$ that differ between isolates B11 and M are indicated. Systemic infection in Solanum commersonii at 20 days postinoculation is indicated to the right. 
(tamarillo strain) by 15 days after sap inoculation, but no plant was systemically infected with isolates B11 or Ali (tobacco strains) by 20 days postinoculation (dpi) (Rajamäki et al. 1998, strain description). However, each isolate infected the inoculated leaves, and the tobacco strain isolates B11 and Ali accumulated typically in 2- to 10-fold higher titers than the other isolates (Table 1). No symptoms developed in inoculated leaves, but the systemically infected leaves displayed a very mild chlorosis.

Leaf-graft experiments were carried out to test whether isolate B11 was blocked at entry into the long-distance transport system (described below). A leaf of $S$. commersonii was grafted onto a tobacco plant (cv. Samsun nn, susceptible to all PVA isolates) and inoculated with isolate B11 or U in two experiments. The inoculated leaves of $S$. commersonii (10 per isolate) were infected, and seven tobacco plants were infected with U, but no tobacco plant was infected with B11 at $18 \mathrm{dpi}$. These data indicated that B11 was not loaded into the longdistance transport system in the leaves of $S$. commersonii.

The plants grown from seeds of the $S$. commersonii accession PI 458319 responded similarly to infection with the PVA isolates. Consequently, crosses and progeny segregating for compatible and incompatible long-distance transport phenotypes could not be produced and studies on genetics of resistance were not carried out.

\section{Viral determinants for systemic infection map to the VPg.}

Two chimeric viruses, in which the HC-Pro- or the CPencoding region of the infectious cDNA of B11 was replaced with the corresponding region from isolate $\mathrm{U}\left(\mathrm{B} 11-\mathrm{U}_{\mathrm{HC}}\right.$ and $\mathrm{B} 11-\mathrm{U}_{\mathrm{CP}}$, respectively; Hämäläinen et al. 2000), were infectious in the inoculated leaves but did not spread systemically in S. commersonii, which was similar to B11 (data not shown). In previous studies, the VPg was identified as an avirulence determinant in PVA; i.e., mutations in the VPg prevented systemic infection of PVA in N. physaloides (Rajamäki and Valkonen 1999) and in a diploid potato hybrid (Hämäläinen et al. 2000) and no disease developed. For these reasons, the VPg was thought to be an avirulence determinant also in $S$. commersonii. A recombinant virus, B11-M, was used, in which a 1,208-nucleotide (nt) region of the infectious cDNA of isolate

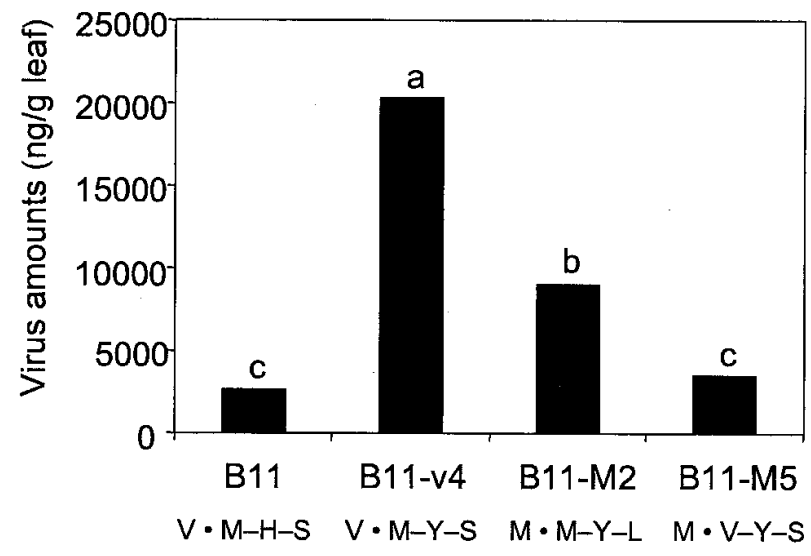

Fig. 3. Accumulation of Potato virus A coat protein antigen in the leaf tissues of Solanum commersonii inoculated by particle bombardment using viral cDNAs. Bars represent means of the virus amounts in leaf disks (nanograms of virus per gram of leaf tissue; number of leaf disks $=19$ ), as determined by enzyme-linked immunosorbent assay at 11 days postinoculation using known amounts of purified virions for comparison. Significantly different means are indicated with different letters. The varied amino acid residues are indicated below the virus names, respectively: amino acid 5 of the $6 \mathrm{~K} 2$ protein, and amino acids 116,118 , and 185 of the viral genome-linked protein (VPg) (Fig. 2).
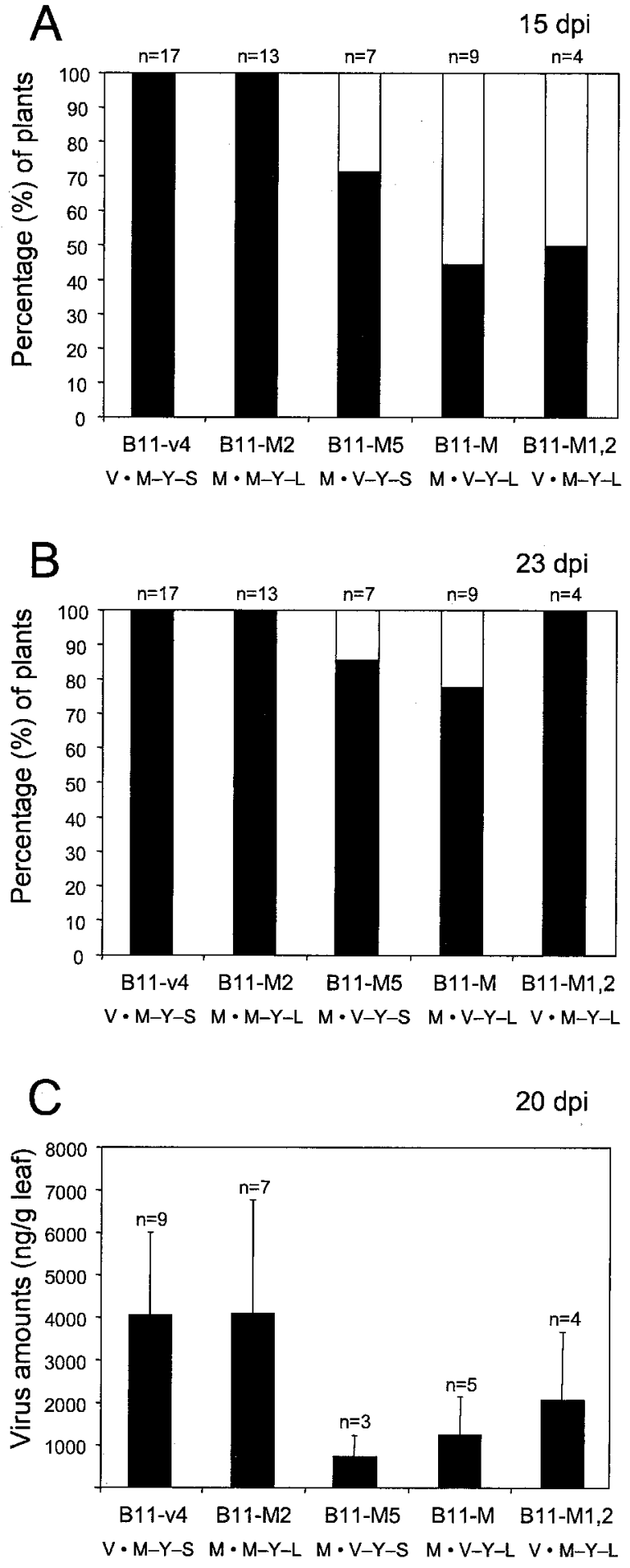

Fig. 4. Percentage of systemically infected plants at A, 15 and $\mathbf{B}, 23$ days postinoculation (dpi), and $\mathbf{C}$, virus accumulation in the systemically infected leaves of Solanum commersonii compared between Potato virus A mutants. A and B, The filled part of bars represents the percentage of plants with detectable amounts of virus in the upper noninoculated leaves as determined by enzyme-linked immunosorbent assay (ELISA). C, The bars represent means of the virus amounts (nanograms of virus per gram of leaf tissue), as determined by ELISA at 20 dpi using known amounts of purified virions for comparison. Standard deviation is indicated on the top of the bars. The total number of plants $(n)$ tested in repeated experiments, each including three or more mutants, is indicated. The varied amino acid residues are indicated below the virus names, respectively: amino acid 5 of the $6 \mathrm{~K} 2$ protein, and amino acids 116,118 , and 185 of the viral genome-linked protein (VPg) (Fig. 2). 
B11 was replaced with the corresponding sequence from isolate M (Rajamäki and Valkonen 1999). The exchanged region encodes for the C-terminal portion of the CI domain, the entire 6K2- and VPg-encoding regions, and a small portion of the $\mathrm{N}$ terminus of the NIa-Pro domain (Fig. 2). In contrast to isolate B11, the recombinant virus B11-M and isolate $\mathrm{M}$ infected $S$. commersonii plants systemically (Fig. 2). Therefore, the avirulence determinant of PVA-B11 was located within the exchanged region.

Four amino acids differ between isolates B11 and $\mathrm{M}$ within the 1,208-nt exchanged region, one in the 6K2 domain and three in the VPg domain (Fig. 2). Each of the amino acids was studied for significance to avirulence by site-directed mutagenesis in both B11 and B11-M (Fig. 2). The terminal leaflets in the three lowest leaves of two to five 4-week-old S. commersonii plants were inoculated by particle bombardment in 2 to 20 experiments, depending on the construct, and a combined sample of leaflets from the upper noninoculated leaves (starting from the third leaf above the inoculated leaves) were tested at 15 and 20 dpi. All constructs infected the inoculated leaves (data not shown).

Results of systemic infection are summarized in Figure 2 and indicate that systemic infection was dependent on a Tyr residue at position 118 of the VPg. In the absence of Tyr at this position, no systemic infection was observed regardless of the aa substitutions in the other three positions in the $6 \mathrm{~K} 2$ protein or the VPg. No sequence reversions were found in the mutated areas, as determined from progeny viruses in systemically infected leaves by reverse-transcription-polymerase chain reaction (RT-PCR) amplification and subsequent restriction analysis or sequencing of the product.

\section{Sequences within the VPg influence virus accumulation in inoculated leaves.}

Accumulation of isolate B11 and three mutants of B11 carrying $\mathrm{Tyr}^{118}$ in the VPg were compared in inoculated leaf tissue (Fig. 3). The substitution of His118Tyr in the VPg was the only aa difference between B11 and the mutant B11-v4 (Fig. 2). Mutants B11-M2 and B11-M5 had two additional aa substitutions relative to B11, both of which had Val5Met in the $6 \mathrm{~K} 2$

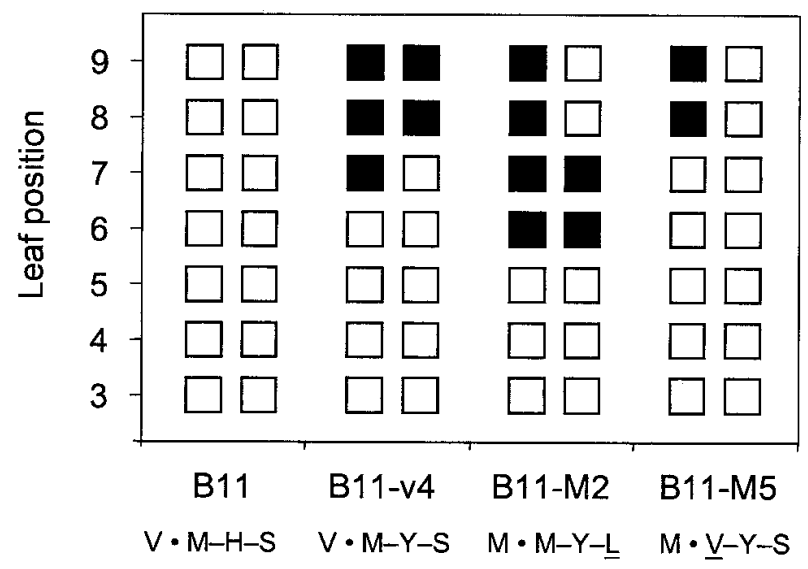

Fig. 5. Partitioning of Potato virus A (PVA) mutants to different sink leaves of Solanum commersonii at 17 days postinoculation. Results are combined from two experiments, each including two to three plants per PVA mutant. Boxes indicate leaves at different positions above the inoculated leaf, and the two stacks of boxes per PVA mutant indicate the two experiments. Filled boxes indicate infected leaves. Inoculated leaves and roots of all tested plants were infected. The varied amino acid residues are indicated below the virus names, respectively: amino acid 5 of the $6 \mathrm{~K} 2$ protein, and amino acids 116,118 , and 185 of the viral genomelinked protein (VPg) (Fig. 2). protein. Additionally, B11-M2 had Ser185Leu and B11-M5 had Met116Val in the VPg (Fig. 2). Virus amounts in leaves inoculated with B11-v4 were sevenfold and fivefold higher than in the leaves inoculated with B11 or B11-M5, respectively, and twofold higher than in leaves inoculated with B11-M2 (Fig. 3). The differences were statistically significant $(P<0.001)$. Clearly, the substitution of His with Tyr at position 118 in the VPg greatly enhanced accumulation of B11 in inoculated leaves, but the extent of enhancement was dependent on amino acids at the other variable positions of the VPg. For example, enhancement of virus accumulation conferred by $\mathrm{Tyr}^{118}$ was prevented in the presence of Val instead of Met at position 116 of the VPg (compare B11-v4 with B11-M5); mutant B11-M5 accumulated to titers no higher than those of isolate B11 (Fig. 3). Nevertheless, B11-M5 infected S. commersonii systemically, in contrast to $\mathrm{B} 11$, and therefore, $\mathrm{Tyr}^{118}$ conferred two independent traits. It was indispensable for phloem loading and systemic infection, and in this respect, its effect was dominant over the effects of amino acids at other variable positions of the VPg. It also increased virus accumulation in inoculated leaves, but this effect could be partially or completely suppressed by the amino acids at the other variable positions of the VPg.

Leu instead of Ser at position 185 reduced virus accumulation (compare B11-M2 with B11-v4), but not as much as Val at position 116 (compare B11-M5 with B11-v4) $(P<0.05)$ (Fig. $3)$. The aa 5 in the $6 \mathrm{~K} 2$ protein was different between B11-v4 (Val) and B11-M2 and B11-M5 (Met). To evaluate its impact on virus accumulation, B11-M2 was compared with B11-M1,2 in additional experiments. These two PVA mutants differ from each other only for the aa 5 of the $6 \mathrm{~K} 2$ protein (Fig. 2). Accumulation of B11-M1,2 (Val) was approximately twofold lower than B11-M2 (Met) in inoculated leaves (data now shown). Taken together, these data indicated that $\mathrm{Val}^{116}$ and $\mathrm{Leu}^{185}$ in the $\mathrm{VPg}$ and $\mathrm{Val}^{5}$ in the $6 \mathrm{~K} 2$ protein affected virus accumulation in inoculated leaves.

\section{Accumulation of viruses in systemically infected leaves.}

Systemic infection was studied using five PVA mutants that contained $\mathrm{Tyr}^{118}$ in the VPg and were, therefore, capable of vascular movement in $S$. commersonii. Mutants B11-v4 and B11-M2 infected all plants of $S$. commersonii systemically by 15 dpi. In contrast, not all plants were systemically infected with B11-M5, B11-M, and B11-M1,2 (Fig. 4A). However, by $23 \mathrm{dpi}$, all plants were systemically infected with the exception of a few plants inoculated with B11-M5 and B11-M (Fig. 4B). In addition to having a faster rate of systemic infection, B11-v4 and B11-M2 also accumulated to higher titers than the other three mutants in the systemically infected leaves (Fig. 4C).

These data indicated that, first of all, Val instead of Met at position 116 of the VPg (B11-M5 and B11-M) caused a delay

Table 2. Infection of the roots of Solanum commersonii with Potato virus $A$ isolates and mutants

\begin{tabular}{lc}
\hline Virus isolate/mutant & Relative amounts of virus in roots \\
\hline B11 & 0 \\
M & 57 \\
U & $100^{\mathrm{b}}$ \\
B11-v4 & 80 \\
B11-M2 & $100^{\mathrm{b}}$ \\
B11-M5 & 8 \\
\hline
\end{tabular}

${ }^{a}$ Virus amounts relative to the isolate that accumulated to the highest amounts in roots at 17 days postinoculation. Virus amounts were estimated by enzyme-linked immunosorbent assay using known amounts of purified virions for comparison. Results are combined from three independent experiments, each including two to three plants per virus isolate.

${ }^{\mathrm{b}}$ Mean amounts of $\mathrm{U}$ and B11-M2 used as the reference $(11,000 \mathrm{ng} / \mathrm{g}=$ 100). 
in systemic infection (Fig. 4A) and reduced virus accumulation in systemically infected leaves (Fig. 4C) similar to what was observed in the inoculated leaves (Fig. 3). Comparison of B11$\mathrm{M} 2$ and B11-M1,2, which differ only for the aa 5 of the $6 \mathrm{~K} 2$ protein, indicated that the presence of $\mathrm{Val}^{5}$ in the $6 \mathrm{~K} 2$ protein resulted in a reduced rate of systemic infection. Similarly, comparison of B11-v4 and B11-M1,2, which differ only for aa 185 of the $\mathrm{VPg}$, revealed that the presence of $\mathrm{Leu}^{185}$ reduced the rate of systemic infection. The reduced rate of systemic infection (Fig. 4) caused by $\mathrm{Val}^{5}$ in the $6 \mathrm{~K} 2$ protein and $\mathrm{Leu}^{185}$ in the VPg was correlated with reduced virus accumulation in inoculated leaves caused by these same aa substitutions (Fig. 3).

\section{Virus distribution to the systemically infected leaves.}

In the experiments described above, systemic infection was detected by sampling one or two leaflets from several upper noninoculated leaves at different positions and combining them for enzyme-linked immunosorbent assay (ELISA). This approach was used in an effort to avoid missing the leaf and leaflets that first became infected. However, two additional experiments were carried out to identify the leaf that first becomes systemically infected with B11-v4, B11-M2, and B11-M5. The sap extracted from each sample at 17 dpi was used for ELISA and immunocapture (IC)-RT-PCR, with both methods giving similar results (data not shown). Additional leaflets from the same leaves were sampled and leaf pieces excised, as shown in Figure 1, to confirm systemic infection with in situ hybridization. The remainder of the leaflets was ground in distilled water, and the sap of each sample was inoculated onto two tobacco seedlings. Inoculation to tobacco was successful from most (79\%), but not all, ELISA-positive samples, which was not surprising since virus amounts were low in some samples (70 to $5,760 \mathrm{ng} / \mathrm{g}$ ) and the amount of leaf tissue used for inoculum was small. Therefore, the results from inoculation tests were taken as additional evidence for the presence of infectious virus in the RT-PCR- and ELISApositive leaves.

The rationale for these experiments was that since leaves are converted from sinks to sources for virus transport while they mature (Roberts et al. 1997), it was expected that delayed systemic infection would be correlated with leaves at a higher position of the plant being the first to become infected. The results suggested that the first leaves systemically infected with B11-M5 were, on average, at least two positions higher than the first leaf infected with B11-M2 and one position higher than the first leaves infected with B11-v4 (Fig. 5). On the other hand, B11-M2 differed from B11-v4 in that the first leaves systemically infected were consistently at a lower position (Fig. 5). Thus, each of the three viruses was differently distributed to the upper noninoculated leaves. Results were well in accordance with data from other experiments indicating a slower rate of systemic infection with B11-M5 as compared with B11M2 and B11-v4 (Fig. 4). The results also suggested that the aa combination $\mathrm{Met}^{5}(6 \mathrm{~K} 2)+\mathrm{Met}^{116}-\mathrm{Tyr}^{118}-\mathrm{Leu}^{185}(\mathrm{VPg})$ at the variable positions provided B11-M2 with the highest efficiency for vascular movement among the PVA mutants tested. This means, in turn, that Leu ${ }^{185}$ in the VPg (B11-M2) is less disadvantageous for vascular movement than $\mathrm{Val}^{5}$ in the $6 \mathrm{~K} 2$ protein (B11-v4) (Fig. 4, substitution Ser185Leu and Met5Val, respectively, reduced the rate of systemic infection).

Systemic infection with PVA was also tested in roots. The relative differences in the levels of accumulation of PVA mutants in roots (Table 2) were similar to that in leaves (Table 1, Figs. 3 and 4C). However, the accumulation of PVA isolates M and $U$ in roots was much higher than in leaves (Tables 1 and 2). Roots were not infected with isolate B11.

\section{Virus localization in inoculated leaves.}

The cellular boundaries restricting phloem loading of isolate B11 in inoculated leaf tissues were investigated at 16 dpi when vascular movement with mutants B11-v4 and B11-M2 had already occurred. Immunostaining with anti-CP antibodies and in situ hybridization with an RNA probe complementary to the PVA CP-encoding sequence were used on consecutive sections for detection of PVA. In situ hybridization enabled a slightly more sensitive detection of PVA than immunostaining, but overall virus localization was similar in the inoculated leaves, regardless of the virus detection method used. As before, B11v4 and B11-M2 infected the plants systemically in these experiments, in contrast to isolate B11. No staining was observed in sections from healthy leaves (Fig. 6I and J).

All types of tissues, including the veins, were strongly stained for the viral $\mathrm{CP}$ and RNA in leaves inoculated with B11-v4 (Fig. 6B, D, F, and H) or B11-M2. In contrast, no major veins (Fig. 6A and $\mathrm{C}$ ) in leaves inoculated with $\mathrm{B} 11$ contained detectable signals for PVA at 16 dpi (12 leaf pieces studied) (Table 3). Furthermore, in minor veins, the occurrence of B11 was rare as compared with B11-v4 and B11-M2 (Fig. 6E, Table 3 ). Analysis of the types of phloem cells containing virusspecific signals in minor veins showed, however, that all three viruses were similarly distributed: all of them infected VPC, but no CC contained detectable signals for PVA (Fig. 6G and $\mathrm{H})$.

In situ hybridization revealed that signals for isolate B11 were always faint (Fig. 6C), in contrast to the strong signals for B11-v4 (Fig. 6D) and B11-M2, which was consistent with the differences in virus titers measured by ELISA (Fig. 3). Also, fewer pieces $(31 \%)$ excised from the leaves inoculated with isolate B11 contained signals for virus, as compared with the leaves inoculated with B11-v4 (75\%) or B11-M2 (100\%). Some of the infection foci of B11 may have gone undetected due to low virus titers in infected cells, but these data may also provide additional evidence for specific resistance to $\mathrm{B} 11$, which was overcome by the aa substitutions in B11-v4 and $\mathrm{B} 11-\mathrm{M} 2$ relative to $\mathrm{B} 11$.

Taken together, the accumulation level of B11 in the infected mesophyll cells was reduced, fewer veins were detectably invaded by B11, and possibly the numbers of successful sites of initial infection with B11 were less than with B11-v4 and B11M2. These differences suggest a low virulence of B11 in $S$. commersonii, which was attributable to a single aa residue, His118, in the VPg.

\section{DISCUSSION}

This study shows that the virus strain-specific resistance to systemic infection with PVA strain B11 in $S$. commersonii is overcome with a single aa substitution at position 118 of the VPg. Leaf-graft experiments showed that vascular transport of B11 is blocked prior to entry into SE. In inoculated leaves of $S$. commersonii, the wild-type B11 accumulated to higher titers than the PVA isolates capable of systemic infection, which indicates that restricted vascular movement of B11 was not attributable to overall low levels of virus accumulation. Studies on several PVA mutants supported this conclusion. Nevertheless, the same aa substitution (His118Tyr) in the VPg also greatly increased the accumulation of B11 in inoculated leaves, and in situ hybridization provided clear evidence for increased titers of viral RNA in infected cells. Importantly, immunostaining for PVA CP and in situ hybridization showed that B11 did not accumulate to detectable levels in the major veins of inoculated leaves. Minor veins account for the majority of veins in a leaf, and B11 was detected in the VPC in some of them, but less commonly than the virulent mutants capable of systemic 
infection. In Nicotiana benthamiana, vascular invasion of Tobacco mosaic virus (TMV, genus Tobamovirus) occurs equivalently via major and minor veins (Cheng et al. 2000). It seems, therefore, that the poor invasiveness and accumulation of B11 in vascular tissues, which was particularly pronounced in major veins, was the main manifestation of resistance that blocked virus entry into the long-distance transport system in $S$. commersonii. The va gene-mediated resistance in tobacco plants has similar effects on infection with Potato virus $Y$ (PVY, genus Potyvirus), but usually causes a delay rather than a block in systemic infection with PVY (Masuta et al. 1999).

The VPC and SE are sparsely, or not at all, connected with plasmodesmata in potato phloem (MacCauley and Evert 1989). Consequently, virus entry into the SE is likely to occur via CC. Other putative routes of entry, e.g., directly from mesophyll to SE via gaps at vein branches or via vein termini (Ding et al. 1998), are less likely, especially because many veins in leaves of $S$. commersonii have no termini but are connected to other veins. No CC with detectable amounts of PVA was found, regardless of the PVA isolate or mutant studied. Considering CC as the conceivable route for phloem loading and unloading, the data suggest that PVA accumulates to only low, undetectable levels in CC of S. commersonii. This is perhaps not so surprising, considering that in $75 \%$ of the minor veins of tomato ( $L y$ copersicon esculentum Mill., family Solanaceae) VPC but no CC contain detectable amounts of TMV (Ding et al. 1998). On the other hand, the majority of minor veins contains $\mathrm{CC}$ and VPC with detectable amounts of PVY in inoculated leaves of tobacco and Nicotiana benthamiana (Ding et al. 1998). Thus, there seem to be virus- and host-dependent differences, either together or separately. Taken together, the data of this study suggest that vascular transport of B11 is blocked at the VPC/CC or CC/SE boundary, or both, in S. commersonii.

Importance of the VPg, its domains, or specific aa residues have not been compared for systemic infection between different host species of any plant virus. The data of this study allow comparison of the virulence phenotypes conferred by the PVA VPg in $N$. physaloides and S. commersonii. It appears that a different aa residue within a central domain of the VPg is crucial for systemic infection, depending on the host species (Fig. 7). Tyr but not His at position 118 allows systemic infection in $S$. commersonii (this study), but both of these aa residues are equally compatible for systemic infection in $N$. physaloides (Rajamäki and Valkonen 1999). On the other hand, Val instead of Met at position 116 is required for normal, efficient systemic infection in N. physaloides (Rajamäki and Valkonen 1999) (Fig. 7 ), but in $S$. commersonii, $\mathrm{Val}^{116}$ reduces virus accumulation and the rate of systemic spread (this study). Only the C-terminal Ser ${ }^{185}$ and Leu ${ }^{185}$ have similar types of effects on systemic infection in both hosts. These data imply that the VPg is a host range determinant, since PVA isolates carrying a certain form of VPg are compatible for efficient systemic infection in one host species but will be restricted to inoculated leaves in another species. This is reminiscent of the role of some other plant virus MPs, such as the tobamovirus 30K MP (Fenczik et al. 1995), as host range determinants.
The polyprotein aa sequence of PVA strain TamMV, including the VPg sequence, is the most different among PVA isolates (Kekarainen et al. 1999). It is noteworthy that TamMV, which lacks Tyr at position 118, could, however, infect S. commersonii systemically. Actually, the VPg aa sequence of TamMV is unique at positions 115 to 120 (SLIHHR, as compared with NVVYYK in isolate $\mathrm{M}$; both compatible for systemic infection in S. commersonii) (Fig. 7) (Kekarainen et al. 1999). Therefore, it is hypothesized that the crucial aa residues in the central domain of the VPg required for overcoming resistance and restoring the compatible virus-host interaction for systemic infection may not necessarily be in direct interaction with putative host factors. Because different aa sequences may be folded to similar structures (Dardick et al. 1999), it is equally possible that the aa sequence at the central domain affects global protein folding. The polar Ser residue versus a hydrophobic Leu residue at position 185 of the PVA VPg C terminus may be important for the same reason. Structural knowledge of potyviral proteins is lacking and does not allow testing hypotheses concerning protein conformation. However, it may be hypothesized that an appropriate $\mathrm{VPg}$ conformation may be needed for interactions with host factors and possibly other viral proteins in a putative "vascular movement complex." Existence of complexes with multiple proteins is suggested by the observed need for additional, adaptive substitutions in other viral proteins, such as the $6 \mathrm{~K} 2$ protein (this study; Rajamäki and Valkonen 1999), the HC-Pro, and the CP, either alone or in combination (Hämäläinen et al. 2000). Direct interaction between the VPg and other potyviral MPs has not been found, but it has been shown that the HC-Pro interacts with the CI (Guo et al. 2001). All potyviral movement-associated proteins, including the VPg, show self-interaction (Guo et al. 2001; López et al. 2001; Oruetxebarria et al. 2001), except for the 6K2 protein that lacks conclusive evidence (D. Guo, M.-L. Rajamäki, and J. Valkonen, unpublished data). It has been proposed that self-interaction of the $\mathrm{CP}$ and the CI is important for assembly of the putative viral movement complexes (Carrington et al. 1996, 1998; López et al. 2001), but whether this is the case, including with the VPg and the HC-Pro, remains to be shown.

Two genes conferring resistance to vascular movement of TEV have been isolated from Arabidopsis (Chisholm et al. 2000; Whitham et al. 2000), and resistance to vascular movement of Pepper mottle virus has been described in pepper (Capsicum annuum L., family Solanaceae) (Guerini and Murphy 1999). It is not reported whether they involve any VPg-host interactions. The resistance mechanism in S. commersonii is unknown. For example, (i) accumulation of B11 in VPC may not reach a putative threshold level required for cellto-cell transport; (ii) subcellular transport of B11 may be defective in VPC or CC; or (iii) B11 may fail to dilate plasmodesmata connecting VPC and CC, and CC and SE, either together or separately. Since the restricted movement of B11 was due to a defective VPg, it follows that any of these mechanisms could involve the VPg, which needs to be studied.

$\mathrm{Tyr}^{118}$ of the PVA VPg was necessary for entry of PVA into SE for vascular transport and it also greatly enhanced the accu-

Table 3. Detection of Potato virus A (PVA) in veins of inoculated leaves at 16 days postinoculation

\begin{tabular}{|c|c|c|c|c|c|c|}
\hline \multirow[b]{3}{*}{ Virus } & \multirow{2}{*}{\multicolumn{2}{|c|}{$\begin{array}{c}\text { Major veins } \\
\text { Classes II to III }\end{array}$}} & \multicolumn{4}{|c|}{ Minor veins } \\
\hline & & & \multicolumn{2}{|c|}{ Classes IV to $\mathrm{V}$} & \multicolumn{2}{|c|}{ Classes VI to VII } \\
\hline & Total $^{\mathrm{a}}$ & Infected (\%) & Total $^{\mathbf{a}}$ & Infected (\%) & Total $^{\mathrm{a}}$ & Infected $(\%)$ \\
\hline B11 & 16 & $0(0)$ & 45 & 8 (18) & 30 & $10(33)$ \\
\hline B11-v4 & 26 & $26(100)$ & 52 & $52(100)$ & 48 & $46(96)$ \\
\hline B11-M2 & 11 & $11(100)$ & 29 & $29(100)$ & 23 & $23(100)$ \\
\hline
\end{tabular}

a The total number of veins examined. Only veins surrounded by leaf tissues apparently infected with PVA were examined for infected cells in the vascular tissue. 




Fig. 6. Localization of Potato virus A (PVA) in inoculated leaves of Solanum commersonii at 16 days postinoculation (dpi) using immunostaining with antibodies to the coat protein $(\mathrm{CP})$ and in situ hybridization with an RNA probe complementary to the CP-encoding sequence. Signals of $\mathbf{A}$, immunostaining (red staining) and $\mathbf{C}$, in situ hybridization (blue staining) are observed in other tissues but not in the internal vascular tissue in a major vein (class II) in consecutive sections prepared from a leaf inoculated with isolate B11. A, The internal vascular tissue is indicated by the positions of adaxial (ADph) and abaxial (ABph) phloem. C, The thick-walled xylem vessels located between ADph and ABph are visible in the same vein. The plant was not systemically infected. However, all tissues, including internal vascular tissue of the major veins, contained signals of $\mathbf{B}$, immunostaining and $\mathbf{D}$, in situ hybridization in a leaf inoculated with the mutant of B11-v4 carrying a single amino acid substitution (His118Tyr) in the viral genome-linked protein (VPg). The plant was systemically infected. Examination of minor veins (classes IV to V) showed that many of them contained no virus-specific signals in the leaves inoculated with E, B11, in contrast to leaves inoculated with F, B11-v4. However, in some of the highest-class veins (class VII), vascular parenchyma cells (arrowhead) were infected with G, B11, similar to H, B11-v4. Mock-inoculated leaves of control plants tested with $\mathbf{I}$, immunostaining or $\mathbf{J}$, in situ hybridization showed no virus-specific signals. Sections were photographed under a light microscope. Magnification: A to D, I, and J, $\times 40 ; \mathbf{E}$ and $\mathbf{F}$, $\times 60$; and $\mathbf{G}$ and $\mathbf{H}, \times 100$. 
mulation of PVA in infected cells of $S$. commersonii, implicating the VPg as an avirulence determinant with two phenotypic effects in the same host genotype. Also, the $v a$-mediated resistance to PVY in tobacco reduces viral cell-to-cell movement in mesophyll and also virus accumulation, especially in the cells of major veins in inoculated leaves (Masuta et al. 1999). A recombinant virus (TEV-GUS ${ }^{\text {Ox5991-Bsu }}$ ) derived from two strains of TEV is blocked for entry into, or exit from, SE in tobacco cv. V20 and accumulates to approximately 100-fold lower titers than the original strains in the protoplasts of tobacco $\mathrm{cv}$. Havana $_{425}$ (Schaad et al. 1997).

Intriguingly, mutations in the same domain of the VPg can be required in several distantly related potyviruses to overcome a phenotypically different resistance in unrelated host species

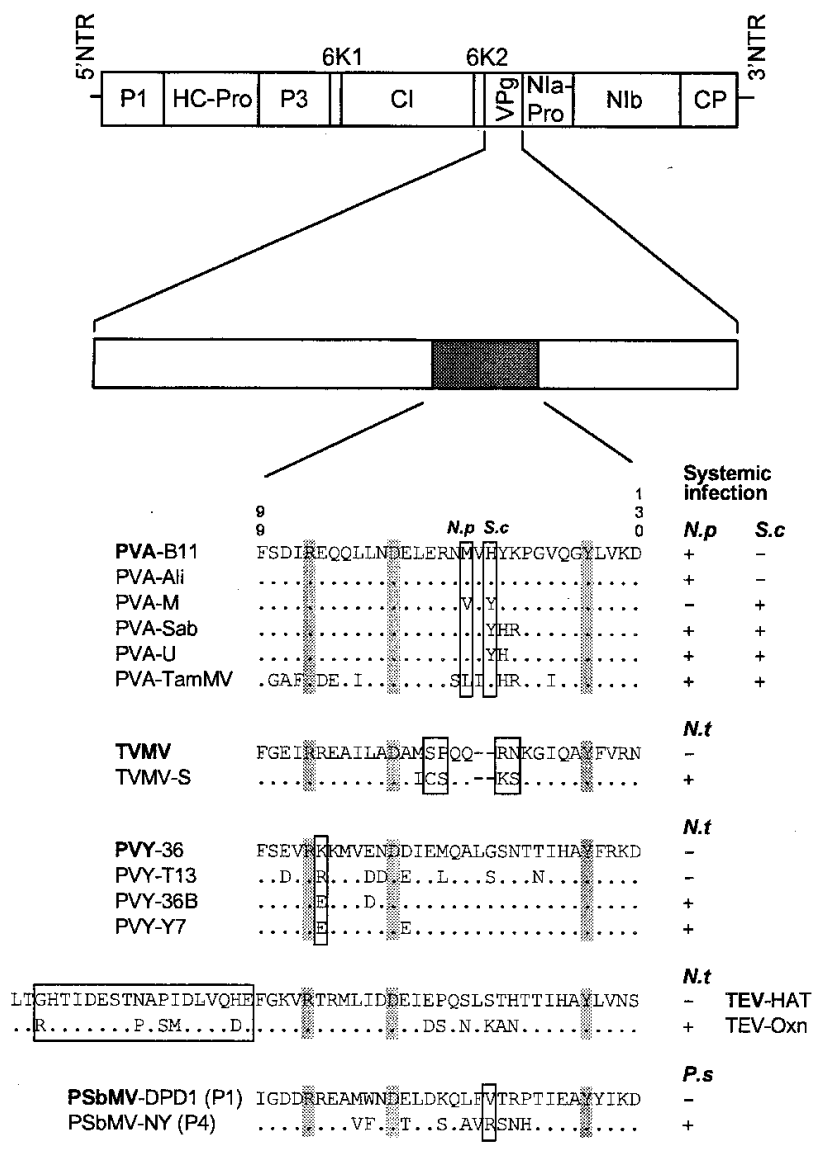

Fig. 7. Schematic map of the potyvirus genome, and comparison of the amino acid positions within a central domain of the viral genome-linked protein (VPg) that are significant for systemic infection in different potyvirus-host combinations. The amino acids conserved within the central domain of the VPg in different potyviruses are shaded. Substitutions in the boxed positions overcome strain-specific resistance to Potato virus A (PVA; Rajamäki and Valkonen 1999), Tobacco vein mottling virus (TVMV; Nicolas et al. 1997), Tobacco etch virus (TEV; Schaad et al. 1997), or Pea seed-borne mosaic virus (PSbMV) (Borgstrøm and Johansen 2001) in host species that restrict systemic infection, as indicated to the right. Unlike other viruses, the implicated amino acid substitutions in Potato virus $Y$ (PVY) have not been confirmed by site-directed mutagenesis of an infectious viral cDNA (Masuta et al. 1999). Resistance to TEV is controlled by two independent recessive genes, whereas resistance to TVMV and PVY is controlled by the same recessive gene $v a$ in tobacco (Nicotiana tabacum). Resistance to PSbMV in pea (Pisum sativum) is controlled by the recessive gene sbm-1. The genetics of resistance to PVA has not been studied. N.p., Nicandra physalodes; N.t., Nicotiana tabacum; P.s. Pisum sativum; and S.c., Solanum commersonii. 5'-NTR and $3^{\prime}$-NTR: 5'- and $3^{\prime}$-nontranslated regions, respectively; P1, proteinase; HC-Pro, helper component-proteinase; P3, the third protein; 6K1 and 6K2, 6-kDa proteins 1 and 2; CI, helicase; NIa-Pro, proteinase; $\mathrm{NIb}$, replicase; and $\mathrm{CP}$, coat protein. (families Fabaceae and Solanaceae). The gene sbm-1 inhibits replication of PSbMV at an early stage of infection in pea plants (Borgstrøm and Johansen 2001). The Arg residue in PSbMV VPg required for overcoming sbm-1 matches with position 118 of the PVA VPg (Fig. 7). On the other hand, the gene $v a$ blocks cell-to-cell movement of TVMV in tobacco mesophyll tissues having no detectable effects on virus replication (Gibb et al. 1989; Nicolas et al. 1997). The four VPg aa residues in TVMV important for overcoming the $v a$-mediated resistance flank the important aa position of PSbMV and PVA (Fig. 7). In PVY and TEV, the important VPg aa residues are located a few positions upstream from the positions important in PVA, TVMV, and PSbMV (Fig. 7). In all these cases, however, the crucial amino acids are distant from the N-proximal amino acids linking the VPg to the viral RNA 5' end (Murphy et al. 1991, 1996), interacting with eIF(iso)4E (Leonard et al. 2000) and responsible for nuclear localization of the VPg (NIa) (Carrington et al. 1991; Schaad et al. 1996). They do not affect self-interaction of the PSbMV VPg (M.-L. Rajamäki and J. Valkonen, unpublished data) or interaction between eIF(iso)4E and TEV NIa (Schaad et al. 2000). While these data do not exclude the possibility that the VPg interacts with several host factors and is an avirulence determinant corresponding to several different resistance mechanisms, a few mechanisms can be envisaged that could be common for the different examples of resistance against potyviruses involving the VPg as an avirulence determinant. They will be proposed as working hypotheses for future studies.

First, aa substitutions in the VPg may induce conformational changes in conjunction with phosphorylation of the $\mathrm{VPg}$, which in turn may affect functions of the VPg in virus movement, replication, or both. The VPg of PVA is phosphorylated by a plant kinase (Ivanov et al. 2001). In TMV, binding of the $30 \mathrm{~K}$ MP to viral RNA represses translation (Karpova et al. 1997), whereas phosphorylation of the 30K MP (Citovsky et al. 1993) abolishes repression of RNA translation (Karpova et al. 1999). Mutations of the phosphorylation sites at the C-terminal part of the $30 \mathrm{~K}$ MP are correlated with its ability to dilate plasmodesmata (Waigmann et al. 2000). Therefore, phosphorylation of the MP may regulate cell-to-cell movement and translation of viral RNA (Karpova et al. 1999; Waigmann et al. 2000). Thus, VPg-kinase interactions could constitute a putative common mechanism affecting viral multiplication and movement in the different potyvirus-host combinations. Second, the VPg may be involved in suppression or circumvention of a general virus defense response. No direct evidence for resistance responses induced or suppressed by the VPg has been obtained, but on the other hand, no study has excluded the possibility (this study; Borgstrøm and Johansen 2001; Keller et al. 1998; Nicolas et al. 1997; Rajamäki and Valkonen 1999; Schaad et al. 1997). For example, it has been proposed that RNA silencing may be hyperactivated in cells controlling access to phloem (Marathe et al. 2000). Consequently, the VPg may suppress a host resistance mechanism (e.g., some phase of RNA silencing), protect viral RNA against degradation, or both.

The VPg determines avirulence in many potyvirus isolatehost genotype combinations restrictive to systemic infection. In all cases, the critical aa residues reside within a short sequence of the central part of the VPg (Fig. 7). Thus, the domain appears to be of universal importance to potyvirus-host interactions during systemic invasion of host plants. This study shows that the central domain of the VPg affects the level of virus accumulation in infected cells, including phloem cells, and controls virus entry to SE for vascular transport. The $\mathrm{C}$ terminus of the VPg forms another domain that affects accumulation and rate of systemic infection in PVA. Identification of the functional domains in the VPg augments future studies on struc- 
ture-function relationships aiming to understand the vascular transport of potyviruses mediated by the VPg.

\section{MATERIALS AND METHODS}

\section{Virus isolates and plants.}

PVA isolates B11, Ali, M, Sab, U, and TamMV have been comprehensively described (Kekarainen et al. 1999; Rajamäki and Valkonen 1999; Rajamäki et al. 1998; Valkonen et al. 1995). The genomic sequence encoding for a C-terminal part of the CI and the complete 6K2 and VPg in Sab was determined in this study (EMBL databank accession no. AJ277992).

Seeds of S. commersonii PI 458319 were obtained from the Potato Introduction Station, Sturgeon Bay, WI, U.S.A. Originally, plants grown from 20 seeds were tested with B11, but no phenotypic differences were detected. Subsequently, a few more seeds were planted and one of these plants was clonally multiplied by taking shoot cuttings. The clone was designated as C1. Experimental conditions have been described (Rajamäki and Valkonen 1999).

\section{Cloning and sequencing.}

All cDNA clones of PVA were constructed to the vector containing the full-length infectious cDNA of PVA-B11 (Puurand et al. 1996) placed under the $35 \mathrm{~S}$ promoter. Cloning was done using standard procedures (Sambrook et al. 1989), and the mutant cDNAs were constructed as described previously (Rajamäki and Valkonen 1999). All mutations were verified by sequencing.

For determination of sequences in PVA isolates or progeny viruses derived from inoculated cDNAs, appropriate fragments were amplified from virus-infected leaves by RT-PCR using PVA-specific primers and cloned as previously described (Rajamäki and Valkonen 1999). Sequencing was carried out as described (Rajamäki and Valkonen 1999) on both strands from at least two independent PCR-amplified clones.

\section{Virus inoculation and detection.}

PVA isolates were propagated in tobacco cv. Samsun nn. Inocula for each virus were adjusted to contain relatively equivalent amounts of virus. Sap inoculation of the three lowest leaves of 4-week-old plants of S. commersonii was carried out as described (Rajamäki and Valkonen 1999). Inoculation of the PVA cDNAs to $S$. commersonii was carried out with the Helios Gene Gun System (Bio-Rad Laboratories, Hercules, CA, U.S.A.). Plasmids containing the viral cDNAs were linearized by AgeI digestion, and cartridges were prepared and inoculation carried out as described previously (Hämäläinen et al. 2000; Kekarainen and Valkonen 2000). Leaves were inoculated with one shot to the middle of the terminal leaflet when plants were 4 weeks old.

In the two leaf-graft experiments, all leaves except the small top leaves were removed from 20 young ( 5 weeks old) tobacco plants. One nearly fully expanded leaf of $S$. commersonii was grafted to the position of one of the removed tobacco leaves at the basal part of the stem. The grafted leaf was bound with Parafilm and the plant was covered with a plastic bag for 5 days to prevent evaporation and wilting of the grafted leaf. Successful formation of the graft union was observed by maintenance of turgor and expansion of the leaf (10 days), after which the leaves of $S$. commersonii were sap-inoculated with PVA isolate B11 or U. Ten leaves were inoculated with each isolate.

Samples from inoculated leaves were excised with a cork borer (Fig. 1), whereas leaflets were picked by hand from the upper noninoculated leaves. PVA infection was detected by double-antibody sandwich-ELISA using a monoclonal antibody (MAb) and an alkaline phosphatase-conjugated MAb to
PVA (MAb 58/0; Adgen, Ayr, U.K.) as described previously (Rajamäki et al. 1998). Samples were weighed and ground in ELISA sample buffer at $1 \mathrm{~g}$ per $3 \mathrm{ml}$, and two aliquots $(100 \mu \mathrm{l})$ were transferred into two wells of a microtiter plate. Known amounts of purified virions of PVA-B11 were included for comparison to estimate the virus concentration in the inoculated leaves and the noninoculated upper leaves.

\section{Immunostaining of thin sections.}

Sampling sites on leaves are indicated in Figure 1. Excised leaf pieces were immediately immersed into fixative ( $4 \%$ formaldehyde) overnight. Preparation of sections $(7 \mu \mathrm{m})$ was carried out as described (Karyeija et al. 2000). Polyclonal antibodies raised in rabbits to the PVA CP were provided by Frank Rabenstein, Institute for Resistance Breeding and Pathogen Diagnostics, Aschersleben, Germany. Samples were initially incubated in phosphate-buffered saline (PBS) containing 4\% bovine serum albumin (BSA) for $30 \mathrm{~min}$ and then incubated with the polyclonal antibodies specific to PVA CP (dilution $1: 100$ ) for $3 \mathrm{~h}$ at room temperature. Dilution of antibodies was done in PBS containing 4\% BSA and 1\% sap extracted from healthy S. commersonii. After washing with PBS, sections were incubated with mouse anti-rabbit MAbs conjugated with alkaline phosphatase (dilution 1:50; Sigma, St. Louis, MO, U.S.A.) for $30 \mathrm{~min}$ at room temperature. After washing in PBS, samples were stained using a fresh fuchsin substrate solution.

\section{In situ hybridization.}

A digoxigenin (DIG)-labeled RNA probe complementary to the CP-encoding sequence of B11 was prepared from the B11 cDNA using an in vitro transcription and DIG RNA Labeling Kit (Roche Diagnostics GmbH, Mannheim, Germany) according to the manufacturer's instructions. DIG-labeled RNA fragments were DNase-treated, concentrated by precipitation, and hydrolyzed to small, approximately 200-nt fragments with alkaline hydrolysis to facilitate probe penetration to plant tissue. In situ hybridization was carried out essentially as described by Jackson (1992). Immunological detection of the hybridized probe was carried out mainly as recommended (Boehringer Mannheim), with the exception of the modifications described by Coen and colleagues (1990).

\section{ACKNOWLEDGMENTS}

We are grateful to H. Kivelä, T. Kekarainen, and I. Oruetxebarria for technical assistance at an initial stage of the study. We thank A. Kvarnheden and U. Pihlgren for kind advice in preparation and immunostaining of thin sections and S. Gunnarsson for assistance in preparation of Figures 1 and 6. Financial support from the Academy of Finland (grants 34529 and 36256), SJFR (grant 32.0667/97), and EC (BIO4CT97-2356) is gratefully acknowledged.

\section{LITERATURE CITED}

Bartels, R. 1971. Potato virus A. No. 54 in: Descriptions of Plant Viruses. Commonw. Mycol. Inst./Assoc. Appl. Biol, Kew, England.

Borgstrøm, B., and Johansen, I. E. 2001. Mutations in Pea seedborne mosaic virus genome-linked protein VPg alter pathotype-specific virulence in Pisum sativum. Mol. Plant-Microbe Interact. 14:707-714.

Carrington, J. C., Freed, D. D., and Leinicke, A. J. 1991. Bipartite signal sequence mediates nuclear translocation of the plant potyviral NIa protein. Plant Cell 3:953-962.

Carrington, J. C., Kasschau, K. D., Mahajan, S. K., and Schaad, M. C. 1996. Cell-to-cell and long-distance transport of viruses in plants. Plant Cell 8:1669-1681.

Carrington, J. C., Jensen, P. E., and Schaad, M. C. 1998. Genetic evidence for an essential role for potyvirus CI protein in cell-to-cell movement. Plant J. 14:393-400.

Chen, Y.-K. H., Bamberg, J. B., and Palta, J. P. 1999. Freezing tolerance and tuber production in selfed and backcross progenies derived from 
somatic hybrids between Solanum tuberosum L. and S. commersonii Dun. Theor. Appl. Genet. 99:100-107.

Cheng, N.-H., Su, C.-L., Carter, S. A., and Nelson, R. S. 2000. Vascular invasion routes and systemic accumulation patterns of tobacco mosaic virus in Nicotiana benthamiana. Plant J. 23:349-362.

Chisholm, S. T., Mahajan, S. K., Whitham, S. A., Yamamoto, M. L., and Carrington, J. C. 2000. Cloning of the Arabidopsis RTM1 gene, which controls restriction of long-distance movement of tobacco etch virus. Proc. Natl. Acad. Sci. U.S.A. 97:489-494.

Citovsky, V., McLean, B. G., Zupan, J. R., and Zambryski, P. 1993. Phosphorylation of tobacco mosaic virus cell-to-cell movement protein by a developmentally regulated plant cell wall-associated protein kinase. Genes Dev. 7:904-910.

Coen, E. S., Romero, J. M., Doyle, S., Elliott, R., Murphy, G., and Carpenter, R. 1990. floricaula: A homeotic gene required for flower development in Antirrhinum majus. Cell 63:1311-1322.

Crawford, K. M., and Zambryski, P. C. 2001. Non-targeted and targeted protein movement through plasmodesmata in leaves in different developmental and physiological states. Plant Physiol. 125:1802-1812.

Cronin, S., Verchot, J., Haldeman-Cahill, R., Schaad, M. C., and Carrington, J. C. 1995. Long-distance movement factor: A transport function of the potyvirus helper component-proteinase. Plant Cell 7: 549-559.

Dardick, C. D., Taraporewala, Z., Lu, B., and Culver, J. N. 1999. Comparison of tobamovirus coat protein structural features that affect elicitor activity in pepper, eggplant, and tobacco. Mol. Plant-Microbe Interact. 12:247-251.

Ding, B. 1998. Intercellular protein trafficking through plasmodesmata. Plant Mol. Biol. 38:279-310.

Ding, X. S., Carter, S. A., Deom, C. M., and Nelson, R. S. 1998. Tobamovirus and potyvirus accumulation in minor veins of inoculated leaves from representatives of the Solanaceae and Fabaceae. Plant Physiol. 116:125-136.

Dolja, V. V., Haldeman, R., Robertson, N. L., Dougherty, W. G., and Carrington, J. C. 1994. Distinct functions of capsid protein in assembly and movement of tobacco etch potyvirus in plants. EMBO (Eur. Mol. Biol. Organ.) J. 13:1482-1491.

Dolja, V. V., Haldeman-Cahill, R., Montgomery, A. E., VandenBosch, K A., and Carrington, J. C. 1995. Capsid protein determinants involved in cell-to-cell and long distance movement of tobacco etch potyvirus. Virology 206:1007-1016.

Eagles, R. M., Gardner, R. C., and Forster, R. L. S. 1990. Nucleotide sequence of the tamarillo mosaic virus coat protein gene. Nucleic Acids Res. 18:7166.

Fellers, J., Wan, J., Hong, Y., Collins, G. B., and Hunt, A. G. 1998. In vitro interactions between a potyvirus-encoded, genome-linked protein and RNA-dependent RNA polymerase. J. Gen. Virol. 79:2043-2049.

Fenczik, C. A., Padgett, H. S., Holt, C. A., Casper, S. J., and Beachy, R N. 1995. Mutational analysis of the movement protein of odontoglossum ringspot virus to identify a host-range determinant. Mol. PlantMicrobe Interact. 8:666-673.

Gibb, K. S., Hellmann, G. M., and Pirone, T. P. 1989. Nature of resistance of a tobacco cultivar to tobacco vein mottling virus. Mol. PlantMicrobe Interact. 2:332-339.

Guerini, M. N., and Murphy, J. F. 1999. Resistance of Capsicum annuum 'Avelar' to pepper mottle potyvirus and alleviation of this resistance by co-infection with cucumber mosaic cucumovirus are associated with virus movement. J. Gen. Virol. 80:2785-2792.

Guo, D., Rajamäki, M.-L., Saarma, M., and Valkonen, J. P. T. 2001. Towards a protein interaction map of potyviruses: Protein interaction matrixes of two potyviruses based on the yeast two-hybrid system. J. Gen. Virol. 82:935-939.

Hayward, H. E. 1938. Solanaceae. Pages 514-549 in: Structure of Economic Plants. Macmillan, New York.

Hämäläinen, J. H., Kekarainen, T., Gebhardt, C., Watanabe, K. N., and Valkonen, J. P. T. 2000. Recessive and dominant genes interfere with the vascular transport of Potato virus $A$ in diploid potatoes. Mol. Plant-Microbe Interact. 13:402-412.

Ivanov, K. I., Puustinen, P., Merits, A., Saarma, M., and Mäkinen, K. 2001. Phosphorylation down-regulates the RNA binding function of the coat protein of Potato virus A. J. Biol. Chem. 276:13530-13540.

Jackson, D. 1992. In situ hybridization in plants. Pages 163-174 in: Molecular Plant Pathology, Vol. 1. S. J. Gun, M. J. McPherson, and D. J. Bowles, eds. IRL Press at Oxford University Press, Oxford, U.K.

Karpova, O. V., Ivanov, K. I., Rodionova, N. P., Dorokhov, Y. L., and Atabekov, J. G. 1997. Nontranslatability and dissimilar behavior in plants and protoplasts of viral RNA and movement protein complexes formed in vitro. Virology 230:11-21.

Karpova, O. V., Radionova, N. P., Ivanov, K. I., Kozlovsky, S. V., Dorokhov, Y. L., and Atabekov, J. G. 1999. Phosphorylation of to- bacco mosaic virus movement protein abolishes its translation repressing ability. Virology 261:20-24.

Karyeija, R. F., Kreuze, J. F., Gibson, R. W., and Valkonen, J. P. T. 2000. Synergistic interactions of a potyvirus and a phloem-limited crinivirus in sweet potato plants. Virology 269:26-36.

Kasschau, K. D., Cronin, S., and Carrington, J. C. 1997. Genome amplification and long-distance movement functions associated with the cen tral domain of tobacco etch potyvirus helper component-proteinase. Virology 228:251-262.

Kekarainen, T., and Valkonen, J. P. T. 2000. Inoculation of viral RNA and cDNA to potato and tobacco plants using the Helios ${ }^{\mathrm{TM}}$ Gene Gun. Technical Note 2351. Bio-Rad Laboratories, Hercules, CA, USA.

Kekarainen, T., Merits, A., Oruetxebarria, I., Rajamäki, M.-L., and Valkonen, J. P. T. 1999. Comparison of the complete sequences of five different isolates of Potato virus A (PVA), genus Potyvirus. Arch. Virol. 144:2355-2366.

Keller, K. E., Johansen, I. E., Martin, R. R., and Hampton, R. O. 1998. Potyvirus genome-linked protein (VPg) determines pea seed-borne mosaic virus pathotype-specific virulence in Pisum sativum. Mol. Plant-Microbe Interact. 11:124-130.

Leonard, S., Plante, D., Wittmann, S., Daigneault, N., Fortin, M. G., and Laliberté, J.-F. 2000. Complex formation between potyvirus VPg and translation eukaryotic initiation factor $4 \mathrm{E}$ correlates with virus infectivity. J. Virol. 74:7730-7737.

López, L., Urzanqui, A., Domínguez, E., and García, J. A. 2001. Identification of an N-terminal domain of the plum pox potyvirus CI RNA helicase involved in self-interaction in a yeast two-hybrid system. J. Gen. Virol. 82:677-686.

Marathe, R., Anandalakshmi, R., Smith, T. H., Pruss, G. J., and Vance, V. B. 2000. RNA viruses as inducers, suppressors and targets of post-transcriptional gene silencing. Plant Mol. Biol. 43:295-306.

Masuta, C., Nishimura, M., Morishita, H., and Hataya, T. 1999. A single amino acid change in viral genome-associated protein of potato virus Y correlates with resistance breaking in 'Virgin A mutant' tobacco. Phytopathology 89:118-123.

McCauley, M. M., and Evert, R. F. 1988a. Morphology and vasculature of the leaf of potato (Solanum tuberosum). Am. J. Bot. 75:377-390.

McCauley, M. M., and Evert, R. F. 1988b. The anatomy of the leaf of potato, Solanum tuberosum L. 'Russet Burbank'. Bot. Gaz. 149:179-195.

McCauley, M. M., and Evert, R. F. 1989. Minor veins of the potato (Solanum tuberosum L.) leaf: Ultrastructure and plasmodesmatal frequency. Bot. Gaz. 150:351-368.

Merits, A., Guo, D., Järvekülg, L., and Saarma, M. 1999. Biochemical and genetic evidence for interactions between potato A potyvirusencoded proteins $\mathrm{P} 1$ and $\mathrm{P} 3$ and proteins of the putative replication complex. Virology 263:15-22.

Murphy, J. F., Rhoads, R. E., Hunt, A. G., and Shaw, J. G. 1990. The VPg of tobacco etch virus RNA is the $49-\mathrm{kDa}$ proteinase or the N-terminal 24-kDa part of the proteinase. Virology 178:285-288.

Murphy, J. F., Rychlik, W., Rhoads, R. E., Hunt, A. G., and Shaw, J. G. 1991. A tyrosine residue in the small nuclear inclusion protein of tobacco vein mottling virus links the VPg to the viral RNA. J. Virol. 65:511-513.

Murphy, J. F., Klein, P. G., Hunt, A. G., and Shaw, J. G. 1996. Replacement of the tyrosine residue that links a potyviral VPg to the viral RNA is lethal. Virology 220:535-538.

Nicolas, O., Dunnington, S. W., Gotow, L. F., Pirone, T. P., and Hellmann, G. M. 1997. Variations in the VPg protein allow a potyvirus to overcome $v a$ gene resistance in tobacco. Virology 237:452-459.

Oparka, K. J., and Turgeon, R. 1999. Sieve elements and companion cells-Traffic control centers of the phloem. Plant Cell 11:739-750.

Oruetxebarria, I., Guo, D., Merits, A., Mäkinen, K., Saarma, M., and Valkonen, J. P. T. 2001. Identification of the genome-linked protein in virions of Potato virus A, with comparison to other members in genus Potyvirus. Virus Res. 73:103-112.

Puurand, Ü., Valkonen, J. P. T., Mäkinen, K., Rabenstein, F., and Saarma, M. 1996. Infectious in vitro transcripts from cloned cDNA of the potato A potyvirus. Virus Res. 40:135-140

Rajamäki, M.-L., and Valkonen, J. P. T. 1999. The 6K2 protein and the VPg of potato virus A are determinants of systemic infection in Nicandra physaloides. Mol. Plant-Microbe Interact. 12:1074-1081.

Rajamäki, M., Merits, A., Rabenstein, F., Andrejeva, J., Paulin, L., Kekarainen, T., Kreuze, J. F., Forster, R. L. S., and Valkonen, J. P. T. 1998. Biological, serological, and molecular differences among isolates of potato A potyvirus. Phytopathology 88:311-321.

Roberts, A. G., Santa Cruz, S., Roberts, I. M., Prior, D. A. M., Turgeon, R., and Oparka, K. J. 1997. Phloem unloading in sink leaves of Nicotiana benthamiana: Comparison of a fluorescent solute with a fluorescent virus. Plant Cell 9:1381-1396.

Ruiz-Medrano, R., Xoconostle-Cazares, B., and Lucas, W. J. 2001. The 
phloem as a conduit for inter-organ communication. Curr. Opin. Plant Biol. 4:202-209.

Sambrook, J., Fritsch, E. F., and Maniatis, T. 1989. Molecular Cloning: A Laboratory Manual, 2nd ed. Cold Spring Harbor Laboratory, Cold Spring Harbor, NY, U.S.A.

Santa Cruz, S. 1999. Perspective: Phloem transport of viruses and macromolecules-What goes in must come out. Trends Microbiol. 7:237241

Schaad, M. C., and Carrington, J. C. 1996. Suppression of long-distance movement of tobacco etch virus in a nonsusceptible host. J. Virol. 70 2556-2561.

Schaad, M. C., Haldeman-Cahill, R., Cronin, S., and Carrington, J. C. 1996. Analysis of the VPg-proteinase (NIa) encoded by tobacco etch potyvirus: Effects of mutations on subcellular transport, proteolytic processing, and genome amplification. J. Virol. 70:7039-7048.

Schaad, M. C., Lellis, A. D., and Carrington, J. C. 1997. VPg of tobacco etch potyvirus is a host genotype-specific determinant for long-distance movement. J. Virol. 71:8624-8631.

Schaad, M. C., Anderberg, R. J., and Carrington, J. C. 2000. Strain-specific interaction of the tobacco etch virus NIa protein with the translation initiation factor eIF4E in the yeast two-hybrid system. Virology 273:300-306.

Seppänen, M. M. 2000. Characterization of freezing tolerance in Solanum commersonii (Dun.), with special reference to the relationship between freezing tolerance and oxidative stress. Ph.D. thesis. Publication no. 56. Department of Plant Production, University of Helsinki, Helsinki, Finland.
Shahabuddin, M., Shaw, J. G., and Rhoads, R. E. 1988. Mapping of the tobacco vein mottling virus VPg cistron. Virology 163:635-637.

Urcuqui-Inchima, S., Haenni, A.-L., and Bernardi, F. 2001. Potyvirus proteins: A wealth of functions. Virus Res. 74:157-175.

Valkonen, J. P. T. 1997. Novel resistances to four potyviruses in tuberbearing potato species, and temperature-sensitive expression of hypersensitive resistance to potato virus Y. Ann. Appl. Biol. 130:91-104.

Valkonen, J. P. T., Puurand, Ü., Slack, S. A., Mäkinen, K., and Saarma M. 1995. Three strain groups of potato A potyvirus based on hypersensitive responses in potato, serological properties, and coat protein sequences. Plant Dis. 79:748-753.

Varrelmann, M., and Maiss, E. 2000. Mutations in the coat protein gene of Plum pox virus suppress particle assembly, heterologous encapsidation and complementation in the transgenic plants of Nicotiana benthamiana. J. Gen. Virol. 81:567-576.

Waigmann, E., Chen, M.-H., Bachmaier, R., Ghosroy, S., and Citovsky, V. 2000. Regulation of plasmodesmal transport by phosphorylation of tobacco mosaic virus cell-to-cell movement protein. EMBO (Eur. Mol. Biol. Organ.) J. 19:4875-4884.

Whitham, S. A., Anderberg, R. J., Chisholm, S. T., and Carrington, J. C. 2000. Arabidopsis RTM2 is necessary for specific restriction of tobacco etc virus and encodes an unusual small heath shock-like protein Plant Cell 12:569-582.

Wittmann, S., Chatel, H., Fortin, M. G., and Laliberté, J. F. 1997. Interaction of the viral protein genome linked of turnip mosaic potyvirus with the translational eukaryotic initiation factor (iso) 4E of Arabidopsis thaliana using the yeast two-hybrid system. Virology 234:84-92. 